\title{
Sewage and sewage-contaminated environments are the most prominent sources to isolate phages against Pseudomonas aeruginosa
}

Bahareh Lashtoo Aghaee ${ }^{1+}$, Mohammadali Khan Mirzaei ${ }^{2+}$, Mohammad Yousef Alikhani ${ }^{1,3,4^{*}}$ and Ali Mojtahedi ${ }^{*^{*}}$

\begin{abstract}
Background: $P$. aeruginosa is the primary source of hospital-acquired infections. Unfortunately, antibiotic resistance is growing to precariously high levels, making the infections by this pathogen life-threatening and hard to cure. One possible alternative to antibiotics is to use phages. However, the isolation of phages suitable for phage therapy — be lytic, be efficient, and have a broad host range — against some target bacteria has proven difficult. To identify the best places to look for these phages against $P$. aeruginosa we screened hospital sewages, soils, and rivers in two cities.
\end{abstract}

Results: We isolated eighteen different phages, determined their host range, infection property, and plaque morphology. We found that the sewage and sewage-contaminated environments are the most reliable sources for the isolation of Pseudomonas phages. In addition, phages isolated from hospital sewage showed the highest efficiency in lysing the bacteria used for host range determination. In contrast, phages from the river had larger plaque size and lysed bacteria with higher levels of antibiotic resistance.

Conclusions: Our findings provided additional support for the importance of sewage as the source of phage isolation.

Keywords: Pseudomonas aeruginosa, Antibiotic resistance, Phage isolation, Phage therapy, Host-range

\section{Introduction}

$P$. aeruginosa is one of the three bacterial pathogens listed as a critical priority for developing new antibiotics, and a leading cause of nosocomial infection $[1,2] . P$. aeruginosa causes infections in multiple organs, including skin, respiratory, urinary, and gastrointestinal tracts

\footnotetext{
* Correspondence: alikhani@umsha.ac.ir; mojtahedi@gums.ac.ir

${ }^{\dagger}$ Bahareh Lashtoo Aghaee and Mohammadali Khan Mirzaei contributed equally to this work.

'Department of Microbiology, Faculty of Medicine, Hamadan University of Medical Sciences, Hamadan, Iran

${ }^{5}$ Department of Microbiology, School of Medicine, Guilan University of Medical Sciences, Rasht, Iran

Full list of author information is available at the end of the article
}

$[3,4]$. Infections by this pathogen are often hard to treat due to the emergence of multidrug resistant strains and the fact that antibiotics are losing their effects [4-6]. Bacterial viruses called phages may provide a solution due to their unique antibacterial characteristics [7-9]. Unlike antibiotics, phages are highly specific, meaning beneficial bacteria stay unharmed during phage treatment $[7,10,11]$. They are also ubiquitous- they outnumber their bacterial host in most ecosystems. The abundance of virus-like particles (VLPs) - which also include phages - in the environment can range from high: $\sim 10^{9} \mathrm{~g}^{-1}$ in wetlands to low: $\sim 10^{3} \mathrm{~g}^{-1}$ in hot deserts in addition to the $\sim 10^{9} \mathrm{~m}^{-2}$ VLPs, which are deposited

(c) The Author(s). 2021 Open Access This article is licensed under a Creative Commons Attribution 4.0 International License, which permits use, sharing, adaptation, distribution and reproduction in any medium or format, as long as you give appropriate credit to the original author(s) and the source, provide a link to the Creative Commons licence, and indicate if changes were made. The images or other third party material in this article are included in the article's Creative Commons licence, unless indicated otherwise in a credit line to the material. If material is not included in the article's Creative Commons licence and your intended use is not permitted by statutory regulation or exceeds the permitted use, you will need to obtain permission directly from the copyright holder. To view a copy of this licence, visit http://creativecommons.org/licenses/by/4.0/. The Creative Commons Public Domain Dedication waiver (http://creativecommons.org/publicdomain/zero/1.0/) applies to the data made available in this article, unless otherwise stated in a credit line to the data. 
from the atmosphere every day [12-14]. Thus, it should be relatively easy and cheap to isolate phages from the environment against multidrug resistant bacteria compared to developing new antibiotics $[9,15]$. However, not all phages are good for therapeutic applications [7, 11]. One limitation of using phages as antibacterial agents is their narrow host range- many phages can only infect a few bacterial strains. Therefore, to fight against the high diversity of bacteria that can cause infection, we would need large numbers of distinct phages [7, 9, 15].

Under existing regulation, all phages must undergo an extensive clinical trial before being applied as antibacterial agents $[7,16,17]$. Thus, using phages with a broader host range can limit the number of phages required to treat infections by different bacterial pathogens, which reduces the cost of clinical trials [15-17]. Using phages with a broad host range could also lead to fewer treatment failures due to an unsuitable phage-host matching when a ready-to-use approach is followed $[9,17,18]$. For phage therapy, most phages are isolated from different environments including, sewage, freshwater, soil, and more- normally where the bacterial hosts exist $[9,15]$. These sources contain the high number of VLPs $[13,14]$ with the highest reported for sewage $\sim 10^{10} \mathrm{ml}^{-1}$ [19], suggesting them as prominent sources for phages isolation. Yet, they differ markedly with respect to physical conditions like temperature, and nutrient availability, which can affect phages-bacteria interactions, and result in selection of phages with specific infection properties [20-24]. Recent metagenomic studies indicated that broad host range phages, infecting several species to multiple phyla, are widely distributed in natural environments [20, 25-27]. Nonetheless, these findings are mainly based on in silico predictions and need further experimental validations. There is also some evidence supporting the existence of broad host range phagescan infect many strains of one species or lyse multiple bacterial species [7, 15, 28, 29]. Taken together, these show the possibility of isolating broad host range phages against different target bacteria from the environment. It will be, therefore, of great interest to identify environmental sources with higher chances to isolated broad host range phages against bacteria with high priority to developing new antibiotics against like $P$. aeruginosa.

To this end, we screened three environmental sources where $P$. aeruginosa is commonly present: sewage, soil, and river [30,31]. We isolated 18 Pseudomonas phages from these environments in different cities, Rasht and Hamadan, in Iran. We next studied their host range using the efficiency of plating (EOP) test and determined the infection properties, latency period, and burst size of three phages. We then analyzed the correlation between the source of isolation and multiple phage characteristics (host range, EOP values, plaque size, plaque morphology, latency period, and burst size) and bacterial features (antibiotic resistance and genetic variation). We demonstrated that phages isolated from different sources tended to have distinct characteristics and infected bacteria with different features.

\section{Materials and methods}

\section{$P$. aeruginosa strains}

Twelve MDR strains with different genomic features, and resistant profiles were selected from a $P$. aeruginosa collection previously isolated from burn wound patients and used in the study for phage isolation [32]. This study was conducted following the Institutional Review Boardapproved studies: IR.UMSHA.REC.1396.923, Hamadan University of Medical Sciences.

\section{Isolation of phages}

We sampled three distinct environmental sources, including hospital sewage, river, and soil from two different cities: Rasht ( $\left.37^{\circ} 16^{\prime} 33^{\prime \prime} \mathrm{N}, 49^{\circ} 35^{\prime} 19^{\prime \prime} \mathrm{E}\right)$ and Hamadan ( $\left.34^{\circ} 47^{\prime} 57^{\prime \prime} \mathrm{N}, 48^{\circ} 30^{\prime} 52^{\prime \prime} \mathrm{E}\right)$. These cities are $360,6 \mathrm{~km}$ away and have a different climate. Hamdan is a mountain city with a height of $1800 \mathrm{~m}$ above sea level. In contrast, Rasht is located close to the Caspian Sea, and it is $8 \mathrm{~m}$ above sea level. From these two cities, we collected a similar number of samples per city/ source, a total of eighteen, from two hospitals, three rivers, and soil from multiple landscapes. The environmental samples were isolated from both contaminated and uncontaminated sites. The collected samples screened for phages using $P$. aeruginosa collection, previously isolated and characterized from burn patients [32]. Specifically, $50 \mathrm{~mL}$ of the water collected from rivers and sewages were centrifuged at $4000 \times \mathrm{g}$ for $30 \mathrm{~min}$ and sterile filtered to remove biological matter. Soils were mixed with phosphate-buffered saline (PBS) at a 1:10 ratio, weight to volume $(\mathrm{w} / \mathrm{v})$, and thoroughly vortexed, centrifuged, and sterile-filtered to separate phages from the organic matter $[1,7,33]$. The filtrates were mixed with equal amounts of doublestrength $\mathrm{LB}$ and $10 \mathrm{~mL}$ of an overnight culture of the target bacteria and incubated for $18 \mathrm{~h}$ at $37^{\circ} \mathrm{C}$. Next, $10 \mathrm{ml}$ of the incubated mix was centrifuged at $4000 \times \mathrm{g}$ for $15 \mathrm{~min}$ and sterile-filtered through a $0.45-\mu \mathrm{m}$ membrane filter. The filtered cultures were tested for phages using a standard plaque assay. Isolated phages were re-isolated by plaque purification from the LB agar plates when multiple phages on the same plate were suspected $[1,7]$.

\section{Host range determination}

We used Efficiency of Plating (EOP) to determine the host range of the isolated phages [7]. Twelve bacterial 
strains to be tested were grown at $37^{\circ} \mathrm{C}$ until they reached OD: 0.08 at $625-\mathrm{nm}$, equivalent to $1.5 \times 10^{8}$ $\mathrm{CFU} / \mathrm{ml}$. We used $200 \mu \mathrm{l}$ of each culture together with $100 \mu \mathrm{l}$ of diluted phage lysate, $10^{6}-10^{9}$ times dilutions from the phage stock, in double-layer plaque assays. All three replicates for each phage were done in parallel on the bacterial strains tested in this study. The plates were incubated for $18 \mathrm{~h}$ at $37^{\circ} \mathrm{C}$, and the number of plaqueforming units (PFU) was counted for each combination. The EOP was calculated (average PFU on target bacteria / average PFU on host bacteria) and presented together with the standard deviation [7] for the three measurements (Table S1 as supplementary file).

\section{One-step growth experiment}

The host bacteria were grown to the exponential phase and infected by phages at the multiplicity of infection of 0.1 and incubated with shaking at $37^{\circ} \mathrm{C}$. Next, $500 \mu \mathrm{L}$ of samples were collected every $10 \mathrm{~min}$, centrifuged, filter-sterilized through a $0.45-\mu \mathrm{m}$ membrane filter, and kept on ice until titration by plaque assay $[1,34]$. The latency periods were calculated as the difference between the time of phage inoculation and the time of the release of phage progenies [34]. Burst sizes were calculated by dividing the average phage titers of the time points after the burst from the initial average of infecting phage titers [1, 34]. The infection property of three phages, vB_PaeM GUMS6, vB_PaeM_GUMS32, and vB_PaeM_GUMS45, were taken from our earlier study [1].

\section{Statistical analysis}

The statistical analyses were conducted in the R opensource software [35]. The stats package was used to run all ANOVAs and t-tests. ggplot2 package was used to create the map [36]. FactoMineR package [37] was used to run the multiple factor analysis (MFA). psych package [38] was used to test the degree of correlation between the quantitative variables using Pearson's correlation coefficient.

\section{Results and discussion}

The lowest number of phages against $P$. aeruginosa were isolated from soil

We isolated eighteen phages from eighteen samples collected from three different environmental sources- eight samples from rivers, six from sewages, and four from soil. Fifty percent of phages were isolated from the river samples- more than two phages per sample on average. In contrast, soil contained lowest number of phages against $P$. aeruginosa- less than one phage per sample on average. Similarly, previous studies on soil isolated 100 phages against Streptomyces avermitilis, a soil bacterium, from 700 samples that were screened [39]. Soil represents one of the most diverse ecosystems on earth, with an interacting community of bacteria, archaea, viruses, fungi, and protozoa [40]. In addition, thousands of bacterial species are living on soil, including many human pathogens, suggesting soil as a viable source for phage isolation [41]. Yet, soil contains a lower number of VLPs $\sim 10^{8} \mathrm{~g}-1$ compared to fresh water and sewage, which might partially explain our results.

\section{Sewage contaminated sites harbored more phages compared to uncontaminated sources}

In addition to uncontaminated environmental sources, we screened a river and a farm contaminated with human wastes to see if the chance of isolating phages against $P$. aeruginosa is higher in those. The large majority of phages isolated from environments were from the contaminated sites. Sewage is suggested as a reliable source for isolating phages against aerobic pathogens due to the high abundance of bacteria associated with humans in them $[9,42]$. Sewage collects material from a large human population, which significantly expands the diversity of microbes living in these systems, which explains the higher number of phages found in environmental sites contaminated with the human waste [43]. However, the number of phages isolated from the sewage-contaminated river was higher than hospital sewages. This came as a surprise as we were expecting more phages to be isolated from hospital sewages than a local river. One possible explanation could be the difference in type of waste going into these sources. The polluted river collects sewage from different origins, including industry, hospitals, farms, and residential areas, while hospital sewages only receive waste from hospitals. Thus, the contaminated river may host a more diverse $P$. aeruginosa community and its phages, as this bacterium can also be found in other sources [44]. Similarly, isolation of phages against multiple human pathogens from Ganges, one of the most polluted rivers in the world, have been previously reported $[45,46]$. In addition, we failed to isolate Pseudomonas phages from the uncontaminated river. The reason might be the lower abundance of bacteria from class Gammaproteobacteria, that includes Pseudomonadaceae family, compared to other taxa that are more abundant like members of phylum Actinobacteria [47-49].

We also isolated different numbers of phages from the two cities in the study. Specifically, two-third of the phages were isolated from Rasht in North of Iran (Fig. 1a). There could be multiple reasons for this, but the higher incidence of $P$. aeruginosa infection cannot be one of them as the limited studies explored this suggested otherwise [50,51]. The higher number of phages isolated from Rasht can be partially explained by the 

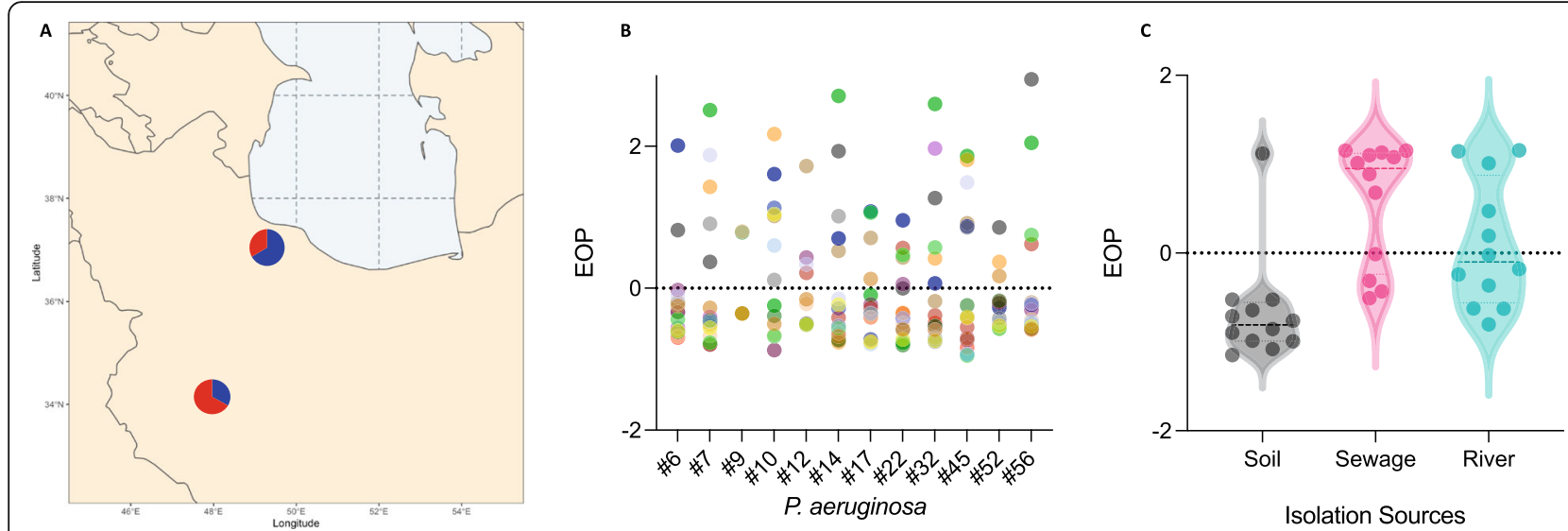

Fig. 1 a Map showing the fraction of phages isolated at different sites. The ratio of phages isolated on each site is in blue. Pie diagrams at $37^{\circ}$

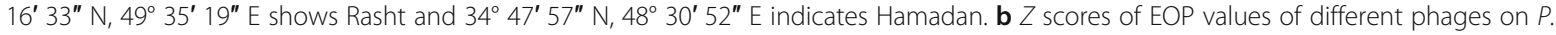
aeruginosa isolates- different colors represent different phages. $\mathbf{c} Z$ scores of phages' EOP values - grouped based on their isolation source. Sewage phages showed the highest EOP values against bacteria used for host range determination

higher population density of this city, $180 / \mathrm{km}^{2}$ vs. $137 /$ $\mathrm{km}^{2}$, which can result in more microbial pollution [52]. The differences between these cities' climates may also play a role as higher microbial diversity is predicted for humid subtropical climates compared to the semi-arid climates [53, 54].

\section{Most isolated phages make the non-halo clear plaques with different sizes}

From eighteen isolated phages, only three are halo, and four are forming turbid plaques. Plaque sizes range from $1 \mathrm{~mm}$ to $4.5 \mathrm{~mm}$, with phages isolated from river tend to make larger plaques on average. Plaque morphology is often used for selecting phages for further characterizations. They can provide information on the phages' replication cycle, the family they might belong to, and if they encode specific enzymatic activities. Specifically, temperate that can choose between lytic and lysogenic cycle typically produces turbid plaques, in contrast to virulent phages form clear plaques $[9,34]$. The family of phages can also be roughly predicted from their plaque morphology. For example, it has been suggested that phages with larger heads like those from the Myoviridae family tend to make smaller plaques $[9,55]$. Moreover, the semi-transparent zones surrounding phage plaques called halo suggest that the phage might encode extracellular polymeric substances (EPS) depolymerase with potential activity against biofilms $[9,55]$.

\section{Phages isolated from sewage had higher EOP values}

Next, we aimed to determine the host range of the isolated phages using the EOP method. The phages' host range were varied between 10 to 12 , with 7 out of 18 phages lysed all 12 bacteria used for host range determination (Fig. 1b and c). Isolated phages showed distinct EOP values on different $P$. aeruginosa strains (Fig. $1 \mathrm{~b}$ and c). The values were also significantly varied from phage to phage, with sewage phages showing the highest efficiency of plating (two-way analysis of variance [ANOVA], Tukey's post hoc test, $p<0.05$ ). For phage therapy, it is highly desirable to use phages that show high virulence on a large number of bacterial strains - an EOP value $\geq 1$ on a target bacterium suggest an efficiency higher or equal to the original host of isolation [7].

\section{Multiple factor analysis of the interactions among phages infection properties, host characteristics, and the source of phage isolation}

We also examined the correlations among multiple phage features (host range, infection properties and plaque morphology), host characteristics (antibiotic resistance pattern, and genetic variation), and sources and geographical region where phages were isolated from using a multiple factor analysis (MFA) framework [33, 56]. This allowed assessing the contribution of sources and geographical regions of isolation to different phage and host features. The first dimension of the MFA explained $25 \%$ of the total variation in the burst size, antibiotic resistance, and plaque size (Fig. 2a, b, and c), and separated variables according to their correlation with phage plaque morphology, and source of isolation (Fig. $2 \mathrm{~d}$, e, and $\mathrm{f}$ ). The second dimension of the MFA explained an additional $19.6 \%$ of the total variability in the EOP value, and latency period (Fig. 2a, b, and c), and largely separated variables correlated to the source of isolation (Fig. 2d, e, and f). In light of these two axes, we found that phages isolated from sewage tended to have 


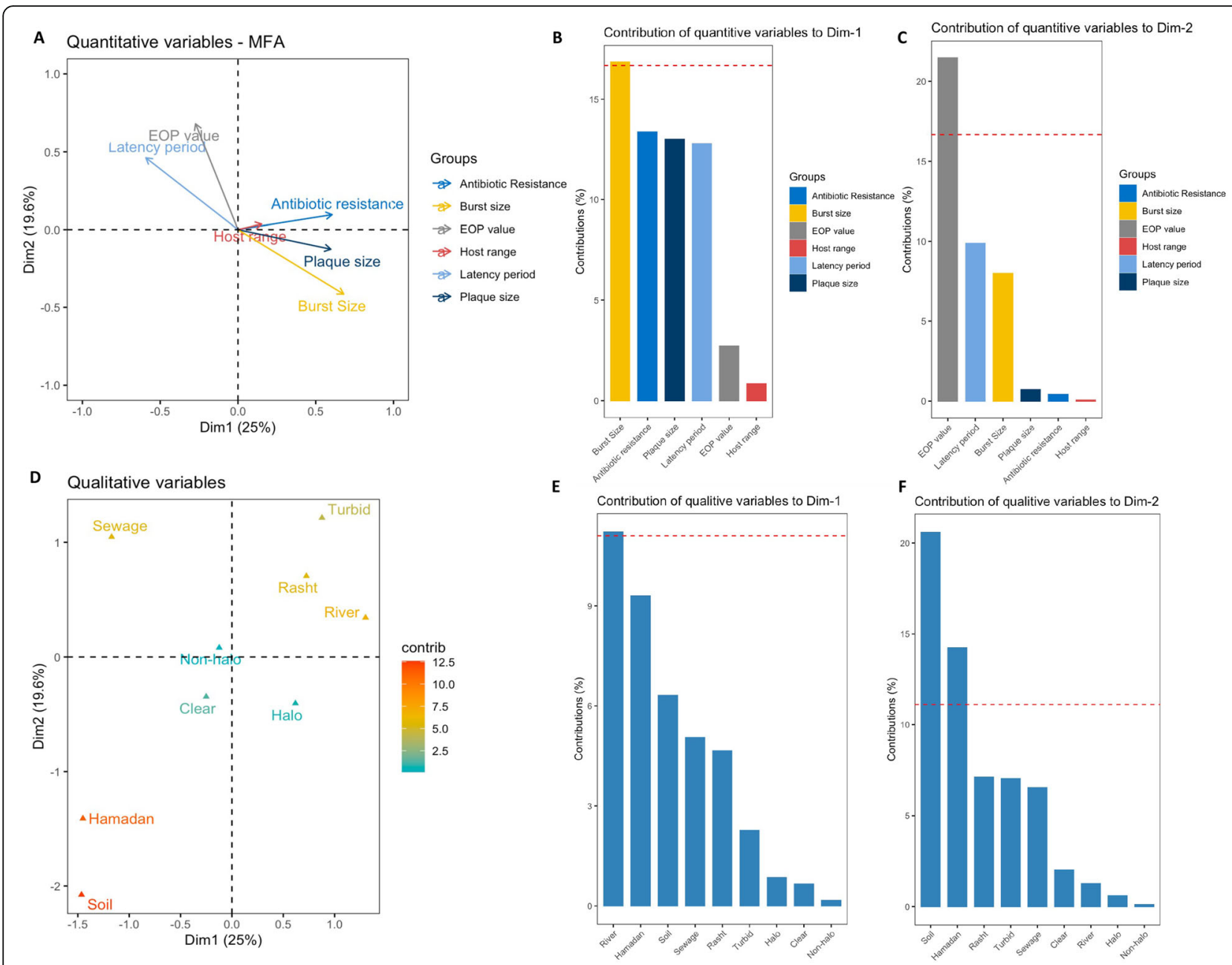

Fig. 2 Multiple Factor Analysis of the phages host range, infection property, source of isolation, and bacterial host characteristics. a MFA ordination of quantitative variables. $\mathbf{b}$ and $\mathbf{c}$ The contribution of each quantitative variable to dimensions 1 and 2 of the MFA. c MFA ordination of qualitative variables. e and $\mathbf{f}$ The contribution of each qualitative variable to dimensions 1 and 2 of the MFA. Quantitative variables include antibiotic resistance, plaque size, host range, EOP value, phages latency period, and burst size- quantitative data were scaled. Qualitative variables include plaque morphology, source and location of isolation, and Pulsed-field Gel Electrophoresis (PFGE) type of the host

higher EOP values and longer latency period, whereas phages isolated from river infected bacteria that were resistant to more antibiotics; they also had larger plaques. In addition, isolated phages could be clustered based on the geographical region, plaque clarity (clear vs. turbid), plaque type (halo vs. non halo), and sources of isolation (Soil, Sewage, and River). The phages isolated from river were more associated with Rasht, whereas phages isolated from soil were linked to Hamadan.

We also ran Pearson's correlation coefficient analysis of the quantitative variables. The EOP values were negatively correlated to host range, plaque size, antibiotic resistant pattern, yet positively correlated to latency period and PFGE type (Fig. 3). As previously suggested, there is a negative correlation among phages' infection propertylatency period and burst size- and the high EOP values, implying a trade-off between phages' replication rate and host range [7, 24]. However, our data for the latency period and the burst size is limited and only include six phages, which makes it difficult to precisely evaluate the trad-off, this has been observed in earlier studies. For example, when phages T1, T4, and $\phi X 174$, were tested against an $E$. coli collection, $\phi X 174$ showed the fastest replication rate but narrowest host range among phages tested [24].

\section{Conclusions}

$P$. aeruginosa is unquestionably one of the most successful pathogens, causing severe nosocomial infections with a high risk of morbidity and mortality in patients $[2,6$, 57]. Infections by this pathogen are becoming harder to treat as conventional antibiotics are less effective [58]. Phages may provide a solution- they are host specific, 


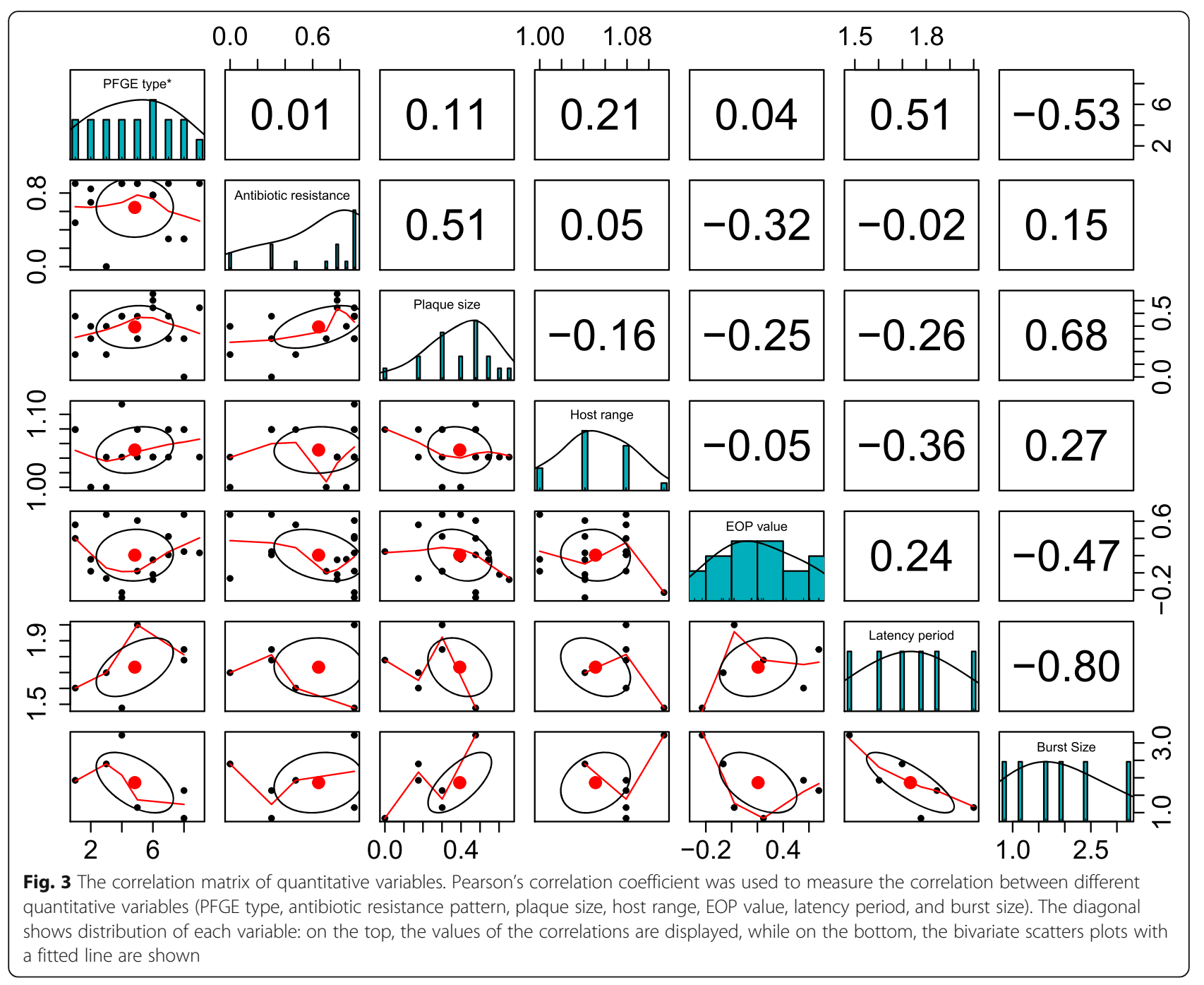

ubiquities, and are constantly developing different strategies to attack bacteria $[18,59]$. Yet, for a phage to be suitable for therapeutic applications, it should be lytic, have a broad host range, and be highly efficient against target bacteria [7, 15, 34]. Phages are typically found in their natural habitats where their hosts are $[9,60]$. However, these habitats may vary in their physical and chemical features, affecting phages-bacteria interactions [54] and selecting for phages with different infection properties. Thereby, it would be helpful to identify environments with a higher probability to contain desirable phages for phage therapy to facilitate the isolation process.

We screened multiple environmental sources in two different cities for isolating phages against $P$. aeruginosa. The samples used in the study were collected from both contaminated and uncontaminated sites. The vast majority of phages were isolated from sewage or sewagecontaminated sources, suggesting human waste as a prominent source for phages isolation against $P$. aeruginosa. These phages also showed the highest EOP values, further emphasizing the importance of sewage as a source for phage isolation. However, we didn't observe a significant difference in the host range of phages isolated from different environment. In addition, we found that phages isolated from the polluted river had larger plaque size and infected bacteria that were resistant to more antibiotics. Yet, our sample size was limited, and we only screened three different sources. To further evaluate the validity of our findings, future studies by including samples with higher heterogeneity (e.g., samples from human, animal, and marine systems) are warranted. With the growing acceptance of phage therapy as an alternative to antibiotic treatment and the increasing demands for phages against different target bacteria, identifying best places to look for specific phages will facilitates phage isolation against emerging pathogenic bacteria.

Going forward, we are planning to determine the kinetics of resistance development in target bacteria against 
isolated phages. This will help to identify phages with less probability to grow resistant against using OmniLog $[9,61]$. This is especially important as, like antibiotics, bacteria can grow resistant to phages. Thus, selecting phages with less likelihood of developing resistance against for phage therapy, will improve the treatment outcomes by preventing the resistant mutants from developing.

\section{Abbreviations}

P. aeruginosa: Pseudomonas aeruginosa; VLPS: Virus-like particles; EOP: Efficiency of plating; MDR: Multidrug-resistant; PBS: Phosphate-buffered saline; CFU: Colony-forming units; PFU: Plaque-forming units; EPS: Extracellular polymeric substances; MFA: Multiple factor analysis

\section{Supplementary Information}

The online version contains supplementary material available at https://doi. org/10.1186/s12866-021-02197-z.

Additional file $\mathbf{1}$ Table S1. The efficiency of plating (EOP), for the eighteen phages on different $P$. aeruginosa isolates. EOP values are presented together with the standard deviation for the three measurements. Data of phages' plaque morphology, infection property, source of isolation, and hosts' antibiotics resistance, and genetic variation are included. The antibiotic resistance section shows the number of distinct antibiotics that the different $P$. aeruginosa strains are resistant to. The average EOP values were used for statistical analysis. $v B$ : viruses of bacteria; Pa: $P$. aeruginosa; NA: not applicable; 0: No plaque was seen; 1: Both host and target bacteria are the same; PFGE: Pulsed-field Gel Electrophoresis.

\section{Acknowledgments}

The authors thank L. Shah Malakpour for proofreading the manuscript. The authors also thank N. Hajipour at Guilan University of Medical Sciences for her technical assistance.

\section{Authors' contributions}

M.K.M., B.A., M.Y.A., and A.M. designed the research; B. A, performed the experiments; M.K.M., analyzed the data; M.K.M., B.A., M.Y.A., and A.M. wrote the paper. All authors approved this version of the manuscript.

\section{Funding}

M.Y.A. is funded by a grant from the Vice-chancellor of Research and Technology, Hamadan University of Medical Sciences, Hamadan, Iran (Grant Number: 97011476). A.M. is supported by a research grant from Vice-chancellor of Research and Technology, Guilan University of Medical Sciences.

\section{Availability of data and materials}

The datasets used and/or analyzed during the current study available from the corresponding author on reasonable request.

\section{Declarations}

\section{Ethics approval and consent to participate}

The study was conducted according to the guidelines of the Declaration of Helsinki, and approved by the Institutional Review Board of Hamadan University of Medical Sciences (protocol code IR.UMSHA.REC.1396.923). Consent to participate not applicable.

\section{Consent for publication}

Not applicable.

\section{Competing interests}

The authors declare no conflict of interest.

\section{Author details}

'Department of Microbiology, Faculty of Medicine, Hamadan University of Medical Sciences, Hamadan, Iran. ${ }^{2}$ Institute of Virology, Helmholtz Center Munich and Technical University of Munich, 85764 Neuherberg, Bavaria, Germany. ${ }^{3}$ Research Center for Molecular Medicine, Hamadan University of Medical Sciences, Hamadan, Iran. ${ }^{4}$ Brucellosis research center, Hamadan University of Medical Sciences, Hamadan, Iran. ${ }^{5}$ Department of Microbiology, School of Medicine, Guilan University of Medical Sciences, Rasht, Iran.

Received: 27 September 2020 Accepted: 15 April 2021

Published online: 01 May 2021

\section{References}

1. Aghaee BL, Khan Mirzaei M, Alikhani MY, Mojtahedi A, Maurice CF. Improving the inhibitory effect of phages against Pseudomonas aeruginosa isolated from a burn patient using a combination of phages and antibiotics. Viruses. 2021;13:334.

2. WHO publishes list of bacteria for which new antibiotics are urgently needed. https://www.who.int/news-room/detail/27-02-2017-who-publishes-list-of-ba cteria-for-which-new-antibiotics-are-urgently-needed. Accessed 23 Feb 2020.

3. Folkesson A, Jelsbak L, Yang L, Johansen HK, Ciofu O, Høiby N, et al. Adaptation of Pseudomonas aeruginosa to the cystic fibrosis airway: an evolutionary perspective. Nat Rev Microbiol. 2012;10:841-51.

4. Church D, Elsayed S, Reid O, Winston B, Lindsay R. Burn wound infections. Clin Microbiol Rev. 2006;19:403-34.

5. Tümmler B. Emerging therapies against infections with Pseudomonas aeruginosa. F1000Res. 2019;8:1. https://doi.org/10.12688/f1000research.19509.1.

6. Bassetti M, Vena A, Croxatto A, Righi E, Guery B. How to manage Pseudomonas aeruginosa infections. Drugs Context. 2018;7:1. https://doi. org/10.7573/dic.212527.

7. Khan Mirzaei M, Nilsson AS. Isolation of phages for phage therapy: a comparison of spot tests and efficiency of plating analyses for determination of host range and efficacy. PLoS One. 2015;10:e0118557. https://doi.org/10.1371/journal.pone.0118557.

8. Abedon ST. Use of phage therapy to treat long-standing, persistent, or chronic bacterial infections. Adv Drug Deliv Rev. 2019;145:18-39.

9. Hyman P. Phages for Phage Therapy: Isolation, Characterization, and Host Range Breadth. Pharmaceuticals (Basel). 2019;12:35. https://doi.org/10.3390/ ph12010035.

10. Khan Mirzaei M, Haileselassie $Y$, Navis M, Cooper C, Sverremark-Ekström E, Nilsson AS. Morphologically distinct Escherichia coli bacteriophages differ in their efficacy and ability to stimulate cytokine release in vitro. Front Microbiol. 2016;7:437. https://doi.org/10.3389/fmicb.2016.00437.

11. Dąbrowska K, Abedon ST. Pharmacologically aware phage therapy: Pharmacodynamic and pharmacokinetic obstacles to phage antibacterial action in animal and human bodies. Microbiol Mol Biol Rev. 2019;83:e00012. https://doi.org/10.1128/MMBR.00012-19.

12. Reche I, D'Orta G, Mladenov N, Winget DM, Suttle CA. Deposition rates of viruses and bacteria above the atmospheric boundary layer. The ISME J. 2018;12:1154-62.

13. Williamson KE, Fuhrmann JJ, Wommack KE, Radosevich M. Viruses in soil ecosystems: an unknown quantity within an unexplored territory. Ann Rev Virol. 2017:4:201-19.

14. Breitbart M. Marine viruses: truth or dare. Annu Rev Mar Sci. 2011;4:425-48.

15. Ross A, Ward S, Hyman P. More is better: selecting for broad host range bacteriophages. Front Microbiol. 2016;7:1352. https://doi.org/10.3389/fmicb.2016. 01352.

16. Cooper CJ, Khan Mirzaei M, Nilsson AS. Adapting drug approval pathways for bacteriophage-based therapeutics. Front Microbiol. 2016;7:1209. https:// doi.org/10.3389/fmicb.2016.01209.

17. Nilsson AS. Pharmacological limitations of phage therapy. Ups J Med Sci. 2019:124:218-27.

18. Mirzaei MK, Maurice CF. Ménage à trois in the human gut: interactions between host, bacteria and phages. Nat Rev Microbiol. 2017:15:397-408.

19. Tamaki H, Zhang R, Angly FE, Nakamura S, Hong P-Y, Yasunaga T, et al. Metagenomic analysis of DNA viruses in a wastewater treatment plant in tropical climate. Environ Microbiol. 2012;14:441-52.

20. Weitz JS, Poisot T, Meyer JR, Flores CO, Valverde S, Sullivan MB, et al. Phagebacteria infection networks. Trends Microbiol. 2013;21:82-91.

21. Díaz-Muñoz SL, Koskella B. Bacteria-phage interactions in natural environments. Adv Appl Microbiol. 2014;89:135-83. 
22. Koskella B, Brockhurst MA. Bacteria-phage coevolution as a driver of ecological and evolutionary processes in microbial communities. FEMS Microbiol Rev. 2014;38:916-31.

23. Fister S, Robben C, Witte AK, Schoder D, Wagner M, Rossmanith P. Influence of environmental factors on phage-Bacteria interaction and on the efficacy and infectivity of phage P100. Front Microbiol. 2016;7:1152.

24. Keen EC. Tradeoffs in bacteriophage life histories. Bacteriophage. 2014;4: e28365. https://doi.org/10.4161/bact.28365.

25. de Jonge PA, Nobrega FL, Brouns SJJ, Dutilh BE. Molecular and evolutionary determinants of bacteriophage host range. Trends Microbiol. 2019;27:51-63.

26. Malki K, Kula A, Bruder K, Sible E, Hatzopoulos T, Steidel S, et al. Bacteriophages isolated from Lake Michigan demonstrate broad host-range across several bacterial phyla. Virol J. 2015;12:164

27. Munson-McGee JH, Peng S, Dewerff S, Stepanauskas R, Whitaker RJ, Weitz JS, et al. A virus or more in (nearly) every cell: ubiquitous networks of virushost interactions in extreme environments. The ISME J. 2018;12:1706-14

28. Gupta R, Prasad Y. Efficacy of polyvalent bacteriophage P-27/HP to control multidrug resistant Staphylococcus aureus associated with human infections. Curr Microbiol. 2011;62:255-60.

29. Pantůcek R, Rosypalová A, Doskar J, Kailerová J, Růzicková V, Borecká P, et al. The polyvalent staphylococcal phage phi 812: its host-range mutants and related phages. Virology. 1998;246:241-52

30. Magalhães MJTL, Pontes G, Serra PT, Balieiro A, Castro D, Pieri FA, et al. Multidrug resistant Pseudomonas aeruginosa survey in a stream receiving effluents from ineffective wastewater hospital plants. BMC Microbiol. 2016; 16:193. https://doi.org/10.1186/s12866-016-0798-0.

31. Kaszab E, Radó J, Kriszt B, Pászti J, Lesinszki V, Szabó Á, et al. Groundwater soil and compost, as possible sources of virulent and antibiotic-resistant Pseudomonas aeruginosa. Int J Environ Health Res. 2019;1:1-13.

32. Karami P, Mohajeri P, Yousefi Mashouf R, Karami M, Yaghoobi MH, Dastan D, et al. Molecular characterization of clinical and environmental Pseudomonas aeruginosa isolated in a burn center. Saudi J Biol Sci. 2019;26:1731-6.

33. Khan Mirzaei M, MdAA K, Ghosh P, Taranu ZE, Taguer M, Ru J, et al. Bacteriophages Isolated from Stunted Children Can Regulate Gut Bacterial Communities in an Age-Specific Manner. Cell Host Microbe. 2020;27:199-212.e5.

34. Hyman P, Abedon ST. Practical methods for determining phage growth parameters. Methods Mol Biol. 2009;501:175-202.

35. R: The R Project for Statistical Computing. https://www.r-project.org/index. html. Accessed 2 Mar 2021

36. Create Elegant Data Visualisations Using the Grammar of Graphics. https:// ggplot2.tidyverse.org/. Accessed 3 Mar 2021.

37. FactoMineR: Exploratory Multivariate Data Analysis with R. http://factominer. free.fr/. Accessed 2 Mar 2021.

38. Revelle W. Psych: procedures for psychological, psychometric, and personality research. 2020. https://CRAN.R-project.org/package=psych. Accessed 2 Mar 2021

39. Greene J, Goldberg RB. Isolation and preliminary characterization of lytic and lysogenic phages with wide host range within the streptomycetes. Gen Microbiol. 1985;131:2459-65.

40. Fierer N. Embracing the unknown: disentangling the complexities of the soil microbiome. Nat Rev Microbiol. 2017:15:579-90.

41. van Overbeek LS, van Doorn J, Wichers JH, van Amerongen A, van Roermund HJW, Willemsen PTJ. The arable ecosystem as battleground for emergence of new human pathogens. Front Microbiol. 2014;5:104.

42. Mattila S, Ruotsalainen $\mathrm{P}$, Jalasvuori M. On-demand isolation of bacteriophages against drug-resistant Bacteria for personalized phage therapy. Front Microbiol. 2015:6:1271. https://doi.org/10.3389/fmicb.2015.01271.

43. Wu L, Ning D, Zhang B, Li Y, Zhang P, Shan X, et al. Global diversity and biogeography of bacterial communities in wastewater treatment plants. Nat Microbiol. 2019:4:1183-95.

44. Noorhosseini SA, Allahyari MS, Damalas CA, Moghaddam SS. Retraction notice to "public environmental awareness of water pollution from urban growth: a case study with Zarjub and Goharrud rivers in Rasht, Iran" [science of the Total environment 599-600 (2017) 2019-2025]. Sci Total Environ. 2019; 693:133595.

45. Menon ND, Kumar MS, Satheesh Babu TG, Bose S, Vijayakumar G, Baswe M, et al. A Novel N4-Like Bacteriophage Isolated from a Wastewater Source in South India with Activity against Several Multidrug-Resistant Clinical Pseudomonas aeruginosa Isolates. mSphere. 2021;6:e01215.
46. Manohar P, Tamhankar AJ, Lundborg CS, Ramesh N. Isolation, characterization and in vivo efficacy of Escherichia phage myPSH1131. PLoS One. 2018;13:e0206278.

47. Wolf A, Wiese J, Jost G, Witzel K-P. Wide geographic distribution of bacteriophages that lyse the same indigenous freshwater isolate (Sphingomonas sp. strain B18). Appl Environ Microbiol. 2003;69:2395-8.

48. Adriaenssens EM, Cowan DA. Using signature genes as tools to assess environmental viral ecology and diversity. Appl Environ Microbiol. 2014;80: 4470-80.

49. Newton RJ, Jones SE, Eiler A, McMahon KD, Bertilsson S. A guide to the natural history of freshwater Lake Bacteria. Microbiol Mol Biol Rev. 2011;75: 14-49.

50. Alikhani MY, Karimi Tabar Z, Mihani F, Kalantar E, Karami P, Sadeghi M, et al. Antimicrobial resistance patterns and prevalence of blaPER-1 and blaVEB-1 genes among ESBL-producing Pseudomonas aeruginosa isolates in west of Iran. Jundishapur J Microbiol. 2014;7:e8888.

51. Nikokar I, Tishayar A, Flakiyan Z, Alijani K, Rehana-Banisaeed S, Hossinpour $M$, et al. Antibiotic resistance and frequency of class 1 integrons among Pseudomonas aeruginosa, isolated from burn patients in Guilan. Iran Iran J Microbiol. 2013;5:36-41.

52. Meadow JF, Altrichter AE, Bateman AC, Stenson J, Brown GZ, Green JL, et al. Humans differ in their personal microbial cloud. PeerJ. 2015:3:e1258.

53. Tseng C-H, Chiang P-W, Shiah F-K, Chen Y-L, Liou J-R, Hsu T-C, et al. Microbial and viral metagenomes of a subtropical freshwater reservoir subject to climatic disturbances. ISME J. 2013;7:2374-86.

54. Farashi A, Shariati M. Biodiversity hotspots and conservation gaps in Iran. J Nat Conserv. 2017;39:37-57.

55. Jurczak-Kurek A, Gąsior T, Nejman-Faleńczyk B, Bloch S, Dydecka A, Topka G, et al. Biodiversity of bacteriophages: morphological and biological properties of a large group of phages isolated from urban sewage. Sci Rep. 2016;6:34338.

56. Borcard D, Gillet F, Legendre P. Numerical Ecology with R. Springer; 2018.

57. Aloush V, Navon-Venezia S, Seigman-Igra Y, Cabili S, Carmeli Y. Multidrugresistant Pseudomonas aeruginosa: risk factors and clinical impact. Antimicrob Agents Chemother. 2006:50:43-8.

58. Laxminarayan R, Duse A, Wattal C, Zaidi AKM, Wertheim HFL, Sumpradit N, et al. Antibiotic resistance — the need for global solutions. Lancet Infect Dis. 2013;13:1057-98.

59. Samson JE, Magadán AH, Sabri M, Moineau S. Revenge of the phages: defeating bacterial defences. Nat Rev Microbiol. 2013;11:675-87.

60. Mirzaei MK, Xue J, Costa R, Ru J, Schulz S, Taranu ZE, et al. Challenges of studying the human Virome - relevant emerging technologies. Trends Microbiol. 2020;29(2):171. https://doi.org/10.1016/j.tim.2020.05.021.

61. Henry M, Biswas B, Vincent L, Mokashi V, Schuch R, Bishop-Lilly KA, et al. Development of a high throughput assay for indirectly measuring phage growth using the OmniLogTM system. Bacteriophage. 2012;2:159-67.

\section{Publisher's Note}

Springer Nature remains neutral with regard to jurisdictional claims in published maps and institutional affiliations.

Ready to submit your research? Choose BMC and benefit from:

- fast, convenient online submission

- thorough peer review by experienced researchers in your field

- rapid publication on acceptance

- support for research data, including large and complex data types

- gold Open Access which fosters wider collaboration and increased citations

- maximum visibility for your research: over $100 \mathrm{M}$ website views per year

At BMC, research is always in progress.

Learn more biomedcentral.com/submission 